\title{
Comparative Evaluation of Urea and Effective Microbes Treated Finger Millet Straw on Feed Intake, Milk Yield and Composition of Lactating Crossbred Dairy Cows at BARC
}

\author{
Tesfaye Mediksa*, Dereje Bekele, Habtamu Aberra, Tesfaye Marsha \\ Bako Agricultural Research Center (BARC), West Shoa, Bako, Ethiopia \\ Email address: \\ tesfishmidoo2008@gmail.com (T. Mediksa) \\ ${ }^{*}$ Corresponding author \\ To cite this article: \\ Tesfaye Mediksa, Dereje Bekele, Habtamu Aberra, Tesfaye Marsha. Comparative Evaluation of Urea and Effective Microbes Treated Finger \\ Millet Straw on Feed Intake, Milk Yield and Composition of Lactating Crossbred Dairy Cows at BARC. International Journal of \\ Agricultural Economics. Vol. 6, No. 3, 2021, pp. 116-121. doi: 10.11648/j.ijae.20210603.14
}

Received: January 13, 2021; Accepted: April 16, 2021; Published: June 16, 2021

\begin{abstract}
The experiment was conducted at Bako agricultural research center to evaluate the effect of EM2 and urea treated finger millet straw supplemented with concentrate mix on feed intake, milk yield and composition of crossbred dairy cows. Four cows of same milk yield, body weight, stage of lactation, but differing parities were arranged in $4 \times 4$ Latin square design. The animals were provided with natural grass hay (T1), untreated finger millet straw (T2), EM2 treated finger millet straw (T3) and urea treated finger millet straw (T4) diet ad libitum and all treatments were supplemented with concentrate mix. Results of chemical analysis of the treated finger millet straw showed that the treated straw had good nutritive value. The daily dry matter $(\mathrm{DM})$ and crude protein $(\mathrm{CP})$ intakes were significantly $(\mathrm{P}<0.001)$ different among the treatments with the highest intake observed for cows fed EM2 and urea treated finger millet straw (T3 and T4). Milk yields varied significantly among the dietary treatments with the lower mean milk yield recorded for cows in T1 and T2 as compared to those in T3 and T4. This study indicated that EM2 and urea treated finger millet straw diet increased the net return. Feeding EM2 and urea treated finger millet straw with concentrate mix was found to be an effective approach to maximize the utilization of locally available feed resources for relatively high animal productivity during the dry season for small scale dairy keepers in rural areas. Therefore, the result demonstrated that EM2 and urea treated finger millet straw had better feeding value as compared to untreated finger millet straw and natural grass hay for lactating crossbred dairy cows.
\end{abstract}

Keywords: Crossbred, Effective Microbe, Finger Millet Straw, Natural Grass Hay and Urea

\section{Introduction}

Feed represents the largest single expense among the inputs for livestock production. Livestock farmers search for inexpensive feed alternatives, especially when conventional feeds are expensive. Many of these alternative feeds are byproducts and waste products from the processing of various food and fibre crops, or crop residues, tree leaves, farm animal wastes etc. There is a need to explore the possibility of utilizing novel feed stuffs, agricultural crop residues, and agro-industrial by-products as complete feed allowance in comprehensive feeding scheme to reduce the feed deficiency and to economize the production (Sudheer Babu et al. 2013). One of such usable crop residues as ruminant animal feed is finger millet straw.

Finger millet straw (FMS) consists of dry stems and leaves. FMS is the by-product obtained after harvesting the crop and can be used as ruminant feed as source of roughage [16]. The straw is available after harvesting, threshing and collecting the grains for human consumption. FMS is considered to have a nutritive value better than other cereals straw [26]. However, still it needs treatment to be available nutrient for better nutritive value therefore it must be supplemented with nitrogen and energy sources to meet maintenance and production requirements [13]. Finger millet straw is readily available especially during the dry season, after the year's harvest. It is cheaper to cure and preserved. Consequently, it could be fed to ruminant animals as a basal feed. 
Nutrient deficiencies affect microbial growth, microbial protein synthesis and overall fermentation in the rumen that further result in low voluntary intake and fiber fermentation and digestibility [15]. The barrier can be removed through biological treatment that increase digestibility by decreasing strength of bonds between lignin and polysaccharides [22, 21]. Biological treatment of crop residues based on the use of enzyme or microbes have shown to improve palatability and degradability potential and keeping quality of the feed material [18]. Feeding effective microbes (EM2) treated hay supplemented with escape protein resulted in remarkable increase in feed efficiency of stationed lactating dairy cows [20]. Biological treatment of maize stover based on the use of enzyme or microbes have shown to improve the quality of feed materials by increasing their palatability and degradability [18]. Therefore, this study was aimed to evaluate the effect of feeding EM2 and urea treated finger millet straw supplemented with concentrate mix on feed intake, milk yield and composition of crossbred dairy cattle.

\section{Materials and Methods}

\subsection{Study Area}

The experiment was carried out at Bako Agricultural Research Center, Ethiopia. The center is located at longitude $37^{\circ} 09^{\prime} \mathrm{E}$, latitude $09^{\circ} 06^{\prime} \mathrm{N}$, an altitude of $1650 \mathrm{~m}$ above sea level and at $260 \mathrm{~km}$ west of the capital city, Addis Ababa.

\subsection{Experimental Animals}

Experimental cows with similar lactation performance, same stage of lactation, body weight, but different parity were selected from the total dairy herd available in Bako Agricultural Research Center. All experimental cows were weighed and de-wormed before starting the experiment.

\subsection{Preparation of Experimental Feeds}

Rhodes grass hay and finger millet straw were used as a basal diet throughout the experimental period. The supplemental concentrate mixture was composed of $49.5 \%$ maize grain $+49.5 \%$ noug seed cake $+1 \%$ salt. The feed supplement was weighed and offered in a separate feed trough twice a day at 8:00 AM and 6:00 PM. The basal diet was fed ad libitum and adjusted up to $20 \%$ refusal level. Feed refusals were collected and weighed before the next feeding. Samples of feed offer and refusals were separately taken and bulked over 30 days for feed intake analysis. Feed intake was calculated as difference of the quantity of feed offered and feed refused. The animals had free access to clean water throughout the experimental periods.

The experimental feeds ingredients used in this study were finger millet straw, natural grass hay, maize grain, Noug seed cake, effective micro-organism (EM2), urea and salt. The Stock EM solution (EM1) used for this study was purchased from the recognized distributer (Woljejii PLC, Debrie-Zeit, Ethiopia). Finger millet straw was used as basal feed both in treated and untreated forms and natural grass hay was also used as untreated form. The straw was manually collected from farms and stored under shade. A 20 litter of EM2 solution was prepared by mixing 1 litter EM1 (stock solution) +1 liter molasses +18 litter water. Then the mixture was stored in a closed plastic container of 25 litter's capacity for 30 days to activate the stock solution. After 30 days a litter of activated EM2 solution was extra diluted by 20 litters of water and sprayed thoroughly on chopped finger millet straw of $20 \mathrm{~kg}$ (on dry matter basis) put in a polyethylene sheet of $100 \mathrm{~m}^{2}(10 \mathrm{~m} * 10 \mathrm{~m})$. This EM2 treated finger millet straw was ensiled for 30 days after which it was used for the lactating crossbred dairy cattle.

Regarding the urea treatment, as in the case of EM2 treatment, the finger millet straw was chopped into the size of $2-3 \mathrm{~cm}$ prior to the ensiling process. Then $5 \mathrm{~kg}$ of urea was dissolved in 100 liters of water and sprinkled uniformly over the $100 \mathrm{~kg}$ of finger millet straw by using sprinkler and buckets. The treated finger millet straw was mixed by using a fork. All mixtures were firmly packed in a silo by trampling to remove air and finally the silo was sealed. The treated finger millet straw was ensiled for 30 days after which it was used for the experimental animals.

The amount of concentrate mix offered daily was at the rate of $0.5 \mathrm{~kg} / \mathrm{l}$ of milk produced by each cow and it was offered with equal portions at 05:00 and 17:00 hours during the morning and evening milking. Adjustments for concentrate offer was made at the end of each period and for each treatment based on the actual milk produced. Adjustment of the basal feed was made weekly based on the amount of refusal weighed every morning, voluntary intake and milk yield of each cow.

\subsection{Experimental Design}

Four lactating crossbred cows were randomly assigned in a switch over 4X4 Latin square design. There were four periods each consisting of 30 days. During the first 15 days of each period, animals were acclimated to the experimental diet and the remaining 15 days were used to collect data. Hence, the experiment took a total of 120 days.

Experimental treatments were

$\mathrm{T} 1$ : Natural grass hay + Concentrate mix $(0.5 \mathrm{~kg} / \mathrm{l}$ of milk)

T2: Untreated finger millet straw + Concentrate mix $(0.5$ $\mathrm{kg} / \mathrm{l}$ of milk)

T3: EM2 treated finger millet straw + Concentrate mix $(0.5$ $\mathrm{kg} / \mathrm{l}$ of milk)

T4: Urea treated finger millet straw + Concentrate mix $(0.5$ $\mathrm{kg} / \mathrm{l}$ of milk)

\subsection{Measurements}

The daily milk yield data of individual cows was taken using a Salter balance. About $100 \mathrm{ml}$ milk sample in the morning and afternoon was taken twice every week during the experiment from each cow into a glass measuring cylinder (100ml capacity) after the milk was thoroughly and gently mixed. Body weight of the animals in each treatment was recorded for two consecutive days at the beginning and 
end of each experimental period to monitor body weight change that may occur as a result of dietary treatments. All samples of feed offered and refusals and faeces were analyzed for DM, ash, N (Kjeldahl-N) according to [2]. Organic matter (OM) was determined as 100 -ash. Crude fiber (CF) and ether extract (EE) was determined by proximate analysis. Neutral detergent fiber (NDF), acid detergent fiber (ADF), and acid detergent lignin (ADL) were determined by the methods of [31]. Invitro organic matter digestibility of feed offered and refusal was determined using the procedures outlined by [28]. The milk samples were used to determine percentage fat, protein and solid not fat (SNF) by Ultrasonic Ekomilk Analyzer (30 w Bulteh 2000, Bulgaria), which have the capacity to measure $20-25$ samples per hour. Total milk solids (TS) were calculated as TS $=\mathrm{SNF}+$ Fat. Calcium and phosphorous content of the offered feeds were analyzed by atomic absorption spectrophotometry and colorimetry [3] respectively.

\subsection{Statistical Analysis}

Voluntary DM and nutrient intakes, live weight change, milk yield and compositions were subjected to GLM procedure for Latin Square Design using Statistical Analysis System [23]. Treatment means were separated using Least Significant difference (LSD). The models used for the analysis of data were:

$$
\text { Yijk }=\mu+C i+P j+T k+E i j k,
$$

Where; $\mu=$ Overall mean, $\mathrm{Ci}=$ Cow effect (parity), $\mathrm{Pj}=$
Period effect, $\mathrm{Tk}=$ Treatment effect and Eijk $=$ Experimental error

\section{Results and Discussions}

\subsection{Chemical Composition of Experimental Feeds}

The chemical composition of natural grass hay, untreated finger millet straw, treated finger millet straw and concentrate mixture are presented in the Table 1. The NDF, $\mathrm{ADF}$, and ADL contents of natural grass hay (NGH) used in this study were higher than that of untreated finger millet straw (UFMS), Urea treated finger millet straw (UTFMS) and Effective microbes treated finger millet straw (EMTFMS). The CP contents were high in UTFMS than EMTFMS and, UFMS. The CP content of concentrate was higher than that of NGH, UTFMS, EMTFMS and UFMS.

The CP content of hay offered to the experimental animals in the current study was comparable 5.1 and $5.6 \%$ of $\mathrm{CP}$ reported by $[7,11]$, respectively while the $\mathrm{CP}$ reported by [1] was 7.02 which is above the current study. It has been stated that $\mathrm{CP}$ value ranging from $7-7.5 \%$ is required to satisfy maintenance requirement of ruminant animals [30]. Hence, the observed $\mathrm{CP}$ content of $\mathrm{NGH}$ in the current study was below demanded for maintenance requirements of dairy cattle. The CP content of finger millet straw in the current study was higher than the value reported by [29], 3.50\% CP and the NDF and ADF contents were 67.05 and $44.00 \%$, respectively which is comparable with the current study.

Table 1. Chemical composition of experimental feeds offered to lactating crossbred dairy cows.

\begin{tabular}{|c|c|c|c|c|c|c|c|c|c|c|c|}
\hline Parameter & DM & ASH & OM & $\mathrm{CP}$ & NDF & ADF & ADL & IVOMD & ME & $\mathrm{Ca}$ & $\mathbf{p}$ \\
\hline UFMS & 90.30 & 10.50 & 89.50 & 4.90 & 69.20 & 43.30 & 18.60 & 52.10 & 7.10 & 1.23 & 0.18 \\
\hline UTFMS & 73.50 & 9.90 & 90.10 & 10.10 & 67.80 & 41.00 & 17.20 & 59.50 & 7.60 & 1.28 & 0.19 \\
\hline EMTFMS & 74.20 & 9.40 & 90.60 & 6.30 & 66.50 & 40.00 & 16.80 & 58.30 & 7.90 & 1.31 & 0.22 \\
\hline $\mathrm{NGH}$ & 92.50 & 11.00 & 89.00 & 5.50 & 71.10 & 46.80 & 6.33 & 48.60 & 6.90 & 1.13 & 0.14 \\
\hline concentrate & 89.70 & 6.20 & 93.80 & 21.50 & 33.30 & 16.20 & 3.10 & 71.20 & 12.90 & 0.17 & 0.96 \\
\hline
\end{tabular}

UFMS: Untreated finger millet straw, UTFMS: Urea treated finger millet straw, EMTFMS: Effective microbes treated finger millet straw, NGH: Natural grass hay, ADF: Acid detergent fiber, CP: Crude protein, DM: Dry matter, NDF: Neutral detergent fiber, OM: Organic matter, ADL: Acid detergent lignin, IVOMD: Invitro organic matter digestibility, ME: Metabolizable energy

Table 2. Nutrient intake of experimental treatment of lactating crossbred dairy cows in $\mathrm{kg} /$ day.

\begin{tabular}{lllllll}
\hline \multirow{2}{*}{ Parameter } & \multicolumn{2}{l}{ Treatments } & \multirow{2}{*}{ Se } & SI \\
\cline { 2 - 5 } & $\mathbf{1}$ & $\mathbf{2}$ & $\mathbf{3}$ & $\mathbf{4}$ & & \\
\hline TDM & $8.23^{\mathrm{b}}$ & $8.09^{\mathrm{b}}$ & $9.50^{\mathrm{a}}$ & $10.15^{\mathrm{a}}$ & 0.233 & $* * *$ \\
OM & $7.39^{\mathrm{b}}$ & $7.21^{\mathrm{b}}$ & $8.60^{\mathrm{a}}$ & $9.14^{\mathrm{a}}$ & 0.209 & $* * *$ \\
$\mathrm{CP}$ & $1.01^{\mathrm{bc}}$ & $0.87^{\mathrm{c}}$ & $1.16^{\mathrm{b}}$ & $1.52^{\mathrm{a}}$ & 0.049 & $* * *$ \\
NDF & $4.69^{\mathrm{c}}$ & $4.59^{\mathrm{c}}$ & $5.16^{\mathrm{b}}$ & $5.52 \mathrm{a}$ & 0.088 & $* * *$ \\
ADF & $2.93^{\mathrm{b}}$ & $2.72^{\mathrm{c}}$ & $3.01^{\mathrm{ab}}$ & $3.18^{\mathrm{a}}$ & 0.049 & $* * *$ \\
ADL & $0.60^{\mathrm{c}}$ & $1.51^{\mathrm{b}}$ & $1.60^{\mathrm{b}}$ & $1.76^{\mathrm{a}}$ & 0.041 & $* * *$ \\
\hline
\end{tabular}

T1: Natural grass hay + Concentrate mix $(0.5 \mathrm{~kg} / \mathrm{l}$ of milk), T2: Untreated finger millet straw + Concentrate mix $(0.5 \mathrm{~kg} / 1$ of milk $)$, T3: EM2 treated finger millet straw + Concentrate mix $(0.5 \mathrm{~kg} / \mathrm{l}$ of milk), T4: Urea treated finger millet straw + Concentrate mix $(0.5 \mathrm{~kg} / \mathrm{l}$ of milk), Se: standard error; ns: non significance, SL: significance level, ADF: Acid detergent fiber, CP: Crude protein, TDM: Total dry matter, NDF: Neutral detergent fiber, OM: Organic matter and ADL: Acid detergent lignin.

\subsection{Feed Intake}

The mean daily DM, CP, OM, NDF ADF and ADL intake of lactating crossbred dairy cows fed EM2 and urea treated Finger millet straw and supplemented with concentrate mix are presented in Table 2. The daily DM, CP, OM, NDF, ADF and ADL intake were significant $(P<0.001)$ among treatments. The highest daily dry matter intake was observed for cows fed with EM2 and urea treated finger millet straw (T3 and T4) as a basal diet. The difference could be attributed to the high rumen degradable protein content of the EM2 and urea treated finger millet compared to the untreated one and the natural grass hay. Such treatment of straws enhances the efficiency of rumen microorganisms to increase fiber degradability and digestibility thereby improving feed intake [17]. The low CP and high fiber contents of the untreated finger millet straw and natural grass hay are likely 
to depress both feed intake and digestibility. NDF is negatively correlated with feed intake and its content above $55 \%$ can limit DM intake [4]. The intake of feeds by ruminants can be improved through concentrate supplementation [19]. Protein meal supplements stimulate intake of low quality roughage diets by providing rumen degradable protein that are deficient in the roughage Earlier report of [16] showed improvement in the daily total DM intake due to supplementation. This may be attributed to the ability of the supplements to provide nitrogen and energy for the cellulolytic microbes upon degradation in the rumen [32].

\subsection{Milk Yield and Composition}

Milk yield and composition of the cows fed experimental feeds are given in Table 3. Daily milk yield was significantly different $(\mathrm{P}<0.05)$ among treatments with higher values for those cows in T3 and T4 as compared to those in T1 and T2. The difference in milk yield among the treatment groups is attributed to the differences in crude protein and energy contents of the diets.

Getu Kitaw [12] and Steinshamn H [25] indicated that lactating crossbred dairy cows fed urea treated wheat straw basal diet produced significantly higher milk yield when supplemented with 50\% vetch (Vicia dasycarpa) diet than the non-supplemented ones because of better nutrient supply. Milk protein, milk fat, solid not fat and total solid contents were non-significant $(\mathrm{P}>0.05)$ among dietary treatments. These findings are similar to work done by [13] where urea and protein supplementation did not alter milk composition. The variation between different reports might be due to the differences in metabolizable energy intake and intrinsic factors like level of production, parity, stage of lactation, external factors like environmental stress, and due to unequal intervals between milking and changes in feeding.

\subsection{Daily Body Weight Change}

The daily mean live weight changes of crossbred dairy cows fed EM and urea treated finger millet straw are shown in Table 3. The mean daily live weight gain was nonsignificant $(\mathrm{P}>0.05)$ among the dietary treatments. The presence of marked differences in nutrient intake among the dietary treatments did not bring a significant effect in weight change of the cows, which may be due to the utilization of additional nutrients consumed for milk production than for weight gain. However body weight loss of $120 \mathrm{~g} /$ day was reported for lactating crossbred cows by [12]. Cows lost body weight after the first phase of the lactation cycle, but with a declining trend. However, improvements in body weight condition of cows have also been observed for all dietary treatments except during the first period of the experiment. This could be probably associated with more diversion of the available nutrients to body tissue accretion.

Table 3. Effect of EM2 and urea treated finger millet straw on milk yield, composition and body weight change of lactating crossbred dairy cows.

\begin{tabular}{lllllll}
\hline \multirow{2}{*}{ Parameters } & \multicolumn{9}{l}{ Treatments } & \multirow{2}{*}{ Se } & \multirow{2}{*}{ SL } \\
\cline { 2 - 5 } & $\mathbf{1}$ & $\mathbf{2}$ & $\mathbf{3}$ & $\mathbf{4}$ & & \\
\hline Milk yield (kg/d) & $6.58^{\mathrm{b}}$ & $6.38^{\mathrm{b}}$ & $8.10^{\mathrm{a}}$ & $7.90^{\mathrm{a}}$ & 0.38 & $*$ \\
Milk fat (\%) & 4.08 & 4.10 & 4.13 & 4.40 & 0.10 & $\mathrm{~ns}$ \\
Milk Protein (\%) & 3.48 & 3.45 & 3.63 & 3.63 & 0.08 & $\mathrm{~ns}$ \\
Solid not fat (\%) & 8.28 & 8.33 & 8.44 & 8.55 & 0.13 & $\mathrm{~ns}$ \\
Total solid (\%) & 12.30 & 11.90 & 13.10 & 12.93 & 0.37 & $\mathrm{~ns}$ \\
Ash & 0.78 & 0.78 & 0.79 & 0.78 & 0.03 & $\mathrm{~ns}$ \\
Bodyweight & 313.9 & 416.6 & 229.2 & 229.2 & 75.52 & $\mathrm{~ns}$ \\
Change (g/day) & & & & & & \\
\hline
\end{tabular}

T1: Natural grass hay + Concentrate mix $(0.5 \mathrm{~kg} / 1$ of milk), T2: Untreated finger millet straw + Concentrate mix $(0.5 \mathrm{~kg} / 1$ of milk), T3: EM2 treated finger millet straw + Concentrate mix $(0.5 \mathrm{~kg} / 1$ of milk), T4: Urea treated finger millet straw + Concentrate mix $(0.5 \mathrm{~kg} / 1$ of milk $)$, Se: standard error, ns: non significance and SL: significance level

Table 4. Partial budget analysis for lactating crossbred dairy cows fed EM2 and Urea treated Finger millet straw basal diet and supplemented with concentrate mix $(0.5 \mathrm{~kg} / \mathrm{kg}$ milk).

\begin{tabular}{|c|c|c|c|c|}
\hline \multirow{2}{*}{ Variable } & \multicolumn{4}{|c|}{ Treatments } \\
\hline & 1 & 2 & 3 & 4 \\
\hline Milk yield (kg/cow/d) & 6.58 & 6.38 & 8.10 & 7.9 \\
\hline Gross field benefit (ETB /cow/d) & 157.92 & 153.12 & 194.4 & 189.6 \\
\hline Cost of NHG (ETB/ kg /cow/d) & 30 & - & - & - \\
\hline Cost of Urea (ETB/ kg /cow/d) & - & - & 5.00 & - \\
\hline Cost of EM2 (ETB/ kg /cow/d) & - & - & - & 6.50 \\
\hline Cost of Finger millet straw (ETB/ kg /cow $/ \mathrm{d})$ & - & 28.00 & 28.00 & 28.00 \\
\hline Cost for Concentrate mix (ETB/kg/cow/d) & 16.45 & 15.95 & 20.25 & 19.75 \\
\hline Cost of Tablet, Mineral and labour (ETB /cow/d) & 20.15 & 20.15 & 20.00 & 20.00 \\
\hline Total variable cost (ETB /cow/d) & 66.6 & 64.1 & 73.25 & 74.25 \\
\hline Gross income, ETB/head & 157.92 & 153.12 & 194.40 & 189.60 \\
\hline Net benefit (ETB cow/d) & 91.32 & 89.02 & 121.15 & 115.35 \\
\hline Change in net income & 2.30 & - & 32.13 & 26.33 \\
\hline Change in total variable cost & 2.50 & - & 9.15 & 10.15 \\
\hline MRR, \% & 92 & - & 351 & 259 \\
\hline
\end{tabular}

ETB: Ethiopian Birr, MRR: Marginal rate of return, T1: Natural grass hay + Concentrate mix $(0.5 \mathrm{~kg} / \mathrm{lof}$ milk), T2: Untreated treated finger millet straw + Concentrate mix $(0.5 \mathrm{~kg} / \mathrm{l}$ of milk), T3: EM2 treated finger millet straw + Concentrate mix $(0.5 \mathrm{~kg} / 1$ of milk $)$ and T4: Urea treated finger millet straw + Concentrate mix $(0.5 \mathrm{~kg} / \mathrm{l}$ of milk) 
Partial Budget Analysis: The economic feasibility of this study was analyzed using partial budget analysis (Table 4). According to this analysis, T3 and T4 gave the highest net benefit (Birr 121.15 and 115.35 per cow/day), while T1 gave the lowest net benefit (Birr 91.32 per cow/day). The minimum rate of return acceptable by a dairy farmer was assumed to be $50 \%$ [5]. This implies that the dairy farmer expects a minimum rate of return of $50 \%$ if he is to adopt a new practice as compared to the practice he used to do. The result of the present study is a little far from the report of [6] which proposed a minimum rate of income of twice the cost of capital as a relevant measure for investments of capital in new technologies. Alternatively, especially for poor farmers in developing countries or for technologies requiring substantial change to a farming system, a minimum rate of income of $100 \%$ (the 2 -for-1 rule) was likely to be more relevant. [8] has also supported this criterion.

Marginal rate of return indicates what farmers can expect to gain on the average in return from their investment when they decide to change from one practice to another. Among the treatment in this study, the largest change in cost that varies was birr 10.15 per day and the corresponding change in net benefits was birr 26.33 per day for T4 resulting in marginal rate of return of $259 \%$.. So for each birr invested in input for a cow, the farmer would recover birr 1 (one) and an additional birr 2.59 at a given prices. Therefore, on the basis of MRR the technology is highly recommended for increasing milk production of the cows, as the returns were much higher than minimum acceptable rate of return (100\%) for any technology to be recommended. The result of MRR of the present study was comparable with the MRR of $158 \%$ and $131.85 \%$ reported, respectively for milking cows and buffaloes fed on urea mineral molasses blocks under an onfarm condition [24].

\section{Conclusion}

Substantial increase in milk production per animal per day and net benefit derived from the increased milk produced indicated that the use of EM2 and urea treated finger millet straw diet is a sound technology for crossbred dairy animals under small scale farmer's condition. Thus it is possible to substantially improve the productivity of crossbred dairy cows in similar production systems by feeding EM2 and urea treated finger millet straw and supplementing concentrate mix.

A rational dairy farmer has to make a compromised decision so that he could opt for a more sustainable milk yield and reasonable profit throughout the entire lactation period, although, this study emphasizes the importance of additional observations to see the likelihood of lactation curve for all dietary treatments in the remaining part of the lactation cycle for conclusive economic decision. Generally, those cows fed basal diet of treated finger millet straw with recommended concentrate mix optimize both biological and economic benefits as compared to cows consumed other treatment rations.

\section{References}

[1] Abebaw Nega, 2007. Effects of supplementation with rice bran, noug seed (Guizotia abyssinica) cake and their mixtures on feed utilization and live weight change of farta sheep. An MSc Thesis Presented to the School of Graduate Studies of Haramaya University. 92p.

[2] AOAC (Association of Analytical Chemist), 1990. Official methods of Analysis. 15 $5^{\text {th }}$ edition. AOAC Inc, Arlington, Virginia, USA.

[3] AOAC (Association of Official Analytical Chemists), 1995. Official Methods of Analysis. pp. 5-13. (16th edition), Washington DC, USA.

[4] Arelovich HM, Abney CS, Vizcarra JA, Galyean PASM (2008). Effects of Dietary Neutral Detergent Fiber on Intakes of Dry Matter and Net Energy by Dairy and Beef Cattle: Analysis of Published Data. The Professional Animal Scientis, 24: $375-383$.

[5] CIMMYT, 1985. From Agronomic Data to Farmers Recommendations. Economics Programme. Mexico. 32p.

[6] CIMMYT, 1988. Agronomic Data to Farmer Recommendations: An Economics Training Manual. Completely Revised Edition. Mexico. 178p.

[7] Ewnetu Ermias, 1999. Between and with in breed variations in feed intake and fat deposition, and genetic associations of these with some production traits in Menz and Horro sheep. An MSc Thesis Presented to the School of Graduate Studies of Alemaya University. 149p.

[8] Farquharson R J, 2006. Production Response and Input Demand in Decision Making: Nitrogen Fertilizer and Wheat Growers. Australasian Agribusiness Review, 14 (5): 35-43.

[9] Garnsworthy, P. C., 1997. Fats in dairy cow diets. In: P. C. Garnsworthy and J. Wiseman (eds.), Recent Advances in Animal Nutrition. Nottingham. University press. 87p.

[10] Gatenby, R. M., 2002. Sheep, The tropical agriculturalist, Macmillan, Oxford, UK. 144p.

[11] Getachew Asefa, 2005. Evaluation of forage yield and effect of forms of feeding of Acacia salignia on intake and live weight gain of Farta sheep fed on grass hay. An MSc Thesis Presented to the School of Graduate Studies of Alemaya University. 66p.

[12] GetuKitaw, 2006. Replacement of formulated Concentrate mix with Vetch (Viciadasycarpa) hay to Lactating crossbred dairy cows fed on urea treated wheat straw. An MSc Thesis Presented to the School of Graduate Studies of Alemaya University. $44 \mathrm{p}$.

[13] Gusha J, Manyuchi CR, Imbayarwo-Chikosi VE, Hamandishe VR, Katsande S, Zvinorova PI (2014). Production and economic performance of F1-crossbred dairy cattle fed nonconventional protein supplements in Zimbabwe. Tropical animal health and production, 46 (1), pp. 229-234.

[14] Heuze V. and Tran G. (2013). Rice straw. Feedipedia, a programme by INRA, CIRAD, AFZand FAO. Available at: http://feedipedia.org/node/557. Retrieved on 14/03/2015. 
[15] Mahesh M. and Madhu M. 2013. Biological treatment of crop residues for ruminant feeding: A review. African Journal of Biotechnology. Vol. 12 (27), pp. 4221-4231, 3 July, 2013.

[16] Malisetty V., Yerradoddi R. R. and Marrivada S. R. (2013). Effect of feeding crop residues based complete rations on growth in ram lambs. Int. J. Sci. Environ. Technol. 2 (1), 1519.

[17] McDonald P, Edwards RA, Greenhalgh JFD, Morgan CA (2002). Animal Nutrition (6 $6^{\text {th }}$ edition). Pearson Educational Limited. Edinburgh, Great Britain. 544p.

[18] Milligan, L. P., Journet, M. and Meng, W. J. (1995). Future areas of research and expected advances in the nutrition of herbivores. In: Journet, M. C., Grenet, E., Farce, M. H., Theriez, M. and Demarquilly, C. (Editors) Recent in development in nutrition of herbivores. Proceeding of $4^{\text {th }}$ International symposium on the nutrition of herbivores INRA Edition Paris pp. 587-610.

[19] Mulu M (2005). Effect of feeding different levels of breweries dried grain on live weight gain and carcass characteristics of Wogera sheep fed on hay basal diet. An MSc Thesis Presented to the school of graduate Studies of Alemaya University of Agriculture, Ethiopia. 139p.

[20] Mulugeta A., 2015. Evaluation of effective microbes (EM) treatment on chemical composition of crop residues and performance of crossbred dairy cows). MSc. Thesis, Haramaya University, Dire Dawa, Ethiopia. 23p.

[21] Peterson, S. J. (2014). Feeding alkaline treated and processed crop residue to feedlot cattle. Thesis and Dissertation in Animal Science paper 93 [http://digitalcommons.unl.edu/animalscidiss/93]. Site visited on $11 / / 1217$.

[22] Russell, J. R., Loy, D. D., Anderson, J. A. and Cecava, M. J. (2011). Potential of chemically treated corn stover and modified distiller grains as partial replacement for corn grain in feedlot diets. Iowa State University Animal Industry Report A. S Leaflet R2586.

[23] SAS (Statistical Analysis System), (2002). SAS Institute Inc, NC, USA.
[24] Shah H, Sharif M, Majid A, Hayat U and Munawar A, 2009: From experimental data to farmer recommendation: an economic analysis of on-farm trial of UMMB feed for milking animals in rain-fed Pothwar, Pakistan. Livestock Research for Rural Development. 21 (117). Retrieved August 11, 2014, from http://www.lrrd.org/lrrd21/8/shah21117.htm

[25] Steinshamn H (2010). Effect of forage legumes on feed intake, milk production and milk quality a review. Animal Science Papers and Reports. 28 (3): 195-206.

[26] Subba Rao A., Prabhu H. U., Seetharam A. and Gowda B. T. S. (1995). Finger Millet. Hand book for straw feeding systems. ICAR, New Delhi, India.

[27] Sudheer Babu A., Srinivasa Rao D., Ramana Reddy Y. and Na-galakshmi D. (2013). Effect of feeding various roughage based processed complete diets on intake and nutrient utilization in ram lambs. Indian J. Anim. Nutr. 30 (3), 252-255.

[28] Tilley, J. M. A. and R. A. Terry, 1963. A two-stage technique for in Vitro digestion of forage crops. Journal of the British Grassland Society, 18: 104.

[29] Umashankar B. C. (2011). Effect of Slow Release Nitrogen Produc on the Performance of Growing Crossbred Calves and Lactating Dairy Cows. Thesis Submitted To The Karnataka Veterinary, Animal and Fisheries Sciences University, Bidar. In Partial Fulfillment of the Requirements for The Award of the Degree of Doctor of Philosophy in Animal Nutrition by Umashankar B. Department of Animal Nutrition and Veterinary College, Bangalore Karnataka Veterinary, Animal and Fisheries Sciences University, Bidar September, 2011.

[30] Van Soest, P. J. Nutritional ecology of the Ruminant. Cornell University. O and B Books, Inc. USA, 1982.

[31] Van Soest, P. J. and J. B. Robertson, 1985. Methods for dietary fiber, neutral detergent fiber and non-starch polysaccharides in Relation to animal Nutrition. Journal of Dairy Science, 74: 3583-3597.

[32] Wambui CC, Abdulrazak SA, Noordin Q (2006). The effect of supplementing urea treated maize stover with tithonia, calliandra and sesbania to growing goats. Livestock Research for Rural Development, 18 (5): 64. 